\title{
Probable ATP-Dependent RNA Helicase DHX58
}

National Cancer Institute

\section{Source}

National Cancer Institute. Probable ATP-Dependent RNA Helicase DHX58. NCI

Thesaurus. Code C158448.

Probable ATP-dependent RNA helicase DHX58 (678 aa, $77 \mathrm{kDa}$ ) is encoded by the human DHX58 gene. This protein is involved in RNA binding and antiviral responses. 